\author{
Dariusz Nowacki (iD) https://orcid.org/0000-0001-8274-8845 \\ Uniwersytet Śląski \\ dariusz.nowacki@us.edu.pl
}

\title{
Obecność Szeli. Trzy przykłady z nowej prozy
}

\author{
Presence of Szela: Three Examples from the New Prose
}

Abstract: The article presents three novels in which the person of Jakub Szela and motif of the Galician slaughter appear. These are Fairy Tale about the Snake's Heart or Another Word about Jakub Szela (2019) by Radek Rak, Deutsch for Intermediates (2019) by Maciej Hen and Galicians (2016) by Stanisław Aleksander Nowak. The starting point for the considerations is the remark of Stanisław Aleksander Nowak who acknowledged the 1846 peasant revolt as a relevant legacy that could support present-day forms of protest against injustice and exploitation. The author of the article examines if the modern prose writers who brought the person of Jakub Szela back to life in their novels truly invoke the aforementioned tradition and if Szela is a rebel icon and an avenger model for them. The result of said examination is negative: the author proves that only pop-cultural or quasi-pop-cultural presence of Szela (in artistic literature) comes into question, which is loosely tied to the broader discussion on "the peasant question" - the so-called plebeian turn in Polish culture, which became most visible in the years of 2015-2016. The author argues that the discussed works of literature do not have the ambitions to deal with the past; the allegedly renounced or unjustly forgotten legacy of peasant resistance and rebellion weren't claimed. Thereby the difference between the demands of the historians and sociologists who reflected anew on the situation of serfs in spirit of the so-called pedagogy of shame and today's literary practice was revealed.

Keywords: Jakub Szela, Radek Rak, Maciej Hen, Stanisław A. Nowak, Galician slaughter, peasant revolt

Streszczenie: Artykuł przynosi omówienie trzech powieści, w których pojawia się postać Jakuba Szeli i wątek rabacji galicyjskiej. Są to Baśń o wężowym sercu albo wtóre stowo o Jakóbie Szeli (2019) Radka Raka, Deutsch dla średnio zaawansowanych (2019) Macieja Hena oraz Galicyanie Stanisława Aleksandra Nowaka (2016). Punktem wyjścia rozważań jest uwaga sformułowana przez Przemysława Czaplińskiego, który bunt chłopski z lutego 1846 roku rozpoznał jako aktualne dziedzictwo, mogące zasilać dzisiejsze formy protestu przeciwko niesprawiedliwości i wyzyskowi. Autor artykułu rozważa, czy rzeczywiście współcześni prozaicy, którzy na kartach swoich powieści ożywili postać Jakuba Szeli, odwołują się do wspomnianej tradycji, czy Szela jest dla nich ikoną buntownika i zarazem wzorem mściciela. Wynik tego sprawdzianu jest negatywny: autor dowodzi, że w grę wchodzi wyłącznie popkulturowa lub quasi-popkulturowa obecność Szeli (w literaturze artystycznej), luźno 
związana z szerszą debatą na temat „kwestii chłopskiej” czy tak zwanym zwrotem plebejskim w polskiej kulturze, jaki najmocniej uwidocznił się w latach 2015-2016. Autor twierdzi, że omówione przez niego utwory nie mają ambicji „rozrachunkowych”; nie upomniano się w nich o rzekomo wyparte czy niesłusznie zapomniane dziedzictwo chłopskiego oporu i buntu. Tym samym ujawniona została rozbieżność między postulatami historyków i socjologów, którzy w ostatnich latach odnowili namysł nad położeniem chłopów pańszczyźnianych w duchu tak zwanej pedagogiki wstydu, a dzisiejszą praktyką literacką.

Słowa kluczowe: Jakub Szela, Radek Rak, Maciej Hen, Stanisław A. Nowak, rabacja galicyjska, bunt chłopski

\section{Uwagi wstępne}

Jakiś czas temu Przemysław Czapliński nakreślił perspektywę wykorzystania przez współczesnych polskich artystów tradycji chłopskiego gniewu. Miał na uwadze zaskakująco odległe dziedzictwo chłopskiej rewolty, które jednak - jego zdaniem - z powodzeniem mogłoby „zasilać wątłe tradycje oporu klasy średniej i prekariatu"'. Czapliński dysponował podówczas tylko jednym, acz niezwykle sugestywnym przykładem manifestacji artystycznej tego rodzaju - spektaklem teatralnym Pawła Demirskiego i Moniki Strzępki W imię Jakuba S. Ów spektakl, jak wiemy, zyskał duży rozgłos; nie tyle wpisał się w zjawisko nazywane „Zwrotem plebejskim” ${ }^{2} \mathrm{w}$ naszej kulturze artystycznej i humanistyce, ile w jakiejś mierze zjawisko to zainicjował (premiera spektaklu odbyła się w grudniu 2011 roku, a szczyt zainteresowania „sprawą chłopską” przypada na lata 20152016). Ponieważ wielokrotnie inwentaryzowano fenomeny składające się na „Zwrot plebejski”, do jakiego doszło w drugiej dekadzie naszego stulecia, nie będę ich tu wymieniał ${ }^{3}$. Bezspornym faktem jest, że sprawa chłopskiego dziedzictwa, w której mieści się tradycja plebejskiego buntu o charakterze odwetowym, eksplodowała z wielką siłą i dość szybko się wypaliła.

Nie sposób ukryć, że nawiązuję tutaj do koniunktury, która przebrzmiała. Ograniczając się tylko do zasobów polskiej prozy, wyraźnie widać, że po roku $2016^{4}$ zainteresowanie problematyką chłopską, wsią tak dawną, jak i współczesną wygasło. Ale figura Jakuba Szeli i temat rabacji galicyjskiej - jeżeli za skromny

1 P. Czapliński, Przemieszczenia. O powojennej prozie chtopskiej [w:] Migracyjna pamięć, wspólnota, tożsamość, red. R. Sendyka, T. Sapota, R. Nycz, Warszawa 2016, s. 205.

2 Kompetentny i bodaj pełny opis tego zjawiska sporządził Paweł W. Ryś - zob. tenże, "Zwrot plebejski” we wspótczesnej polskiej humanistyce i debacie publicznej [w:] Historia, interpretacja, reprezentacja, t. 3, red. L. Mokrzecki, M. Brodnicki, J. Taraszkiewicz, Gdańsk 2015.

${ }^{3}$ Całkiem niedawno kolejny katalog sporządził Grzegorz Grochowski - zob. tenże, Kwestia chtopska [w:] Chtopska (nie)pamięć. Dziedzictwo chtopskości w polskiej literaturze i kulturze, red. G. Grochowski, D. Krawczyńska, G. Wołowiec, Kraków 2019, s. 7-11.

${ }^{4}$ W latach 2014-2015 ukazały się powieści, napisane przez młodych lub względnie młodych autorów, które przedstawiono jako utwory świadczące o pojawieniu się nowej fali prozy 
dowód mogą posłużyć trzy powieści (dwie ogłoszone jesienią 2019 roku, trzecia trzy lata wcześniej) - wydają się atrakcyjne dla współczesnych prozaików. Aliści to, co zwróciło moją uwagę i bezpośrednio przyczyniło się do powstania niniejszej wypowiedzi, sprowadza się do pytania o formy obecności Szeli (w nowej prozie). Ścieżka nakreślona przez Czaplińskiego - przynajmniej w świetle moich trzech przykładów - okazała się przejawem myślenia życzeniowego. Owszem, pojawiają się próby interpretowania najnowszych opowieści o Szeli na podstawie „dyrektyw” czy „instrukcji” pochodzących z czasu - by tak rzec antypańszczyźnianego wzmożenia (tu zwłaszcza silne oddziaływanie przeboju polskiej humanistyki Prześnionej rewolucji Andrzeja Ledera), jedną z nich za chwilę przedstawię, ale trudno je uznać za przekonujące. Wiele wskazuje na to, że sugestywny spektakl Demirskiego i Strzępki - ów mocny, koronny argument w wywodach Czaplińskiego - był jednorazowym aktem artystycznej brawury. Jak na razie nie doczekał się, jakkolwiek pojmowanej, literackiej bądź teatralnej kontynuacji, a pytania-pretensje podrzucone przez Ledera w innym miejscu pozostają bez odpowiedzi. Warto je przypomnieć:

Czy doczekamy się Quentina Tarantino, który opowie we współczesny sposób zwyczajne bicie, wypędzenie, głód? I upokorzenie, które się z tym wiązało. I zajadłą wściekłość, która musiała się w ludziach gromadzićc?5

Godzi się zauważyć, że w wypowiedziach krytyków literackich, eseistów i publicystów zabierających głos w sprawie odzyskiwania wypartego chłopskiego dziedzictwa naszkicowano tylko jeden tryb powrotu Szeli, jedną perspektywę odnowienia legendy „zbója galicyjskiego” - to modus „rebeliancki”. Z grubsza rzecz ujmując, chodziło o fantazmat mściciela, właśnie w guście Tarantinowskim ${ }^{6}$, figurę, która byłaby dobrą odpowiedzią na często podnoszone rozpoznanie, że współczesna opresja kapitalistyczna oraz reżim korporacyjny są głębinowo osadzone w kulturze folwarcznej, a położenie chłopa pańszczyźnianego - to lejtmotyw sztuki Wimię Jakuba S. - w niewielkim stopniu różni się

wiejskiej: Guguty Wioletty Grzegorzewskiej, Sońka Ignacego Karpowicza, Podkrzywdzie Andrzeja Muszyńskiego, Skoruń Macieja Płazy.

5 A. Leder, Nienapisana epopeja. Kilka uwag o zapomnianym wyzwoleniu, „Teksty Drugie" 2016, nr 6, s. 227.

${ }^{6}$ Po napisaniu tego artykułu ukazała się monografia Michała Rauszera (Bękarty pańszczyzny. Historia buntów chtopskich, Warszawa 2020), będąca podsumowaniem zainicjowanych około 2016 roku prac tego autora na temat poddaństwa polskich chłopów i wszczynanych przez nich buntów. Już sam tytuł tego opracowania odsyła do przewrotnej wyobraźni Quentina Tarantino; wydaje się również gestem etycznym. Wszak filmowa opowieść Inglourious Basterds (2009), znana u nas pod tytułem Bękarty wojny, nie tylko podsuwa problem „legalnej”, w pełni uzasadnionej przemocy o charakterze odwetowym, ale także zachęca nas do przyjęcia nieoczywistego stanowiska (brutalne mordy na nazistach jako „słuszne” czyny podjęte przez amerykańskich Żydów, tytułowych „bękartów”). 
od sytuacji kogoś, kto dziś zaciągnął kredyt hipoteczny (niewolnik banku jako obecne wcielenie niewolnika na roli).

\section{Zbój magiczny. Baśń o wężowym sercu albo wtóre stowo o Jakóbie Szeli Radka Raka}

Lektura najwcześniejszych, rozsianych w sieci ${ }^{7}$ wypowiedzi na temat powieści Radka Raka poucza, że Baśń o wężowym sercu to utwór niezwykle łaskawy. Mam na uwadze mnogość „punktów zaczepienia”, rozmaitość porządków, w których dzieło to może być rozpatrywane. Wskazywano zatem na baśniowość, treści inicjacyjne, reinterpretację legendy o Szeli, inicjatywę stylistyczną, obrazowanie typowe dla starszej i nowszej fantastyki; dostrzeżono także potencjał krytyczny rzekomo tkwiący w tym utworze (Baśń... miałaby być literacką odpowiedzią na postulat przedstawienia ludowej historii Polski). Na tym tle wyróżnił się jeden komentarz (zaznaczam, że akurat w pełni profesjonalny) - Stanisław Krawczyk omówił utwór Raka jednowymiarowo, odwołując się do wspomnianego już przeboju Andrzeja Ledera. Nie tylko w ten sposób, że niektóre tezy zawarte w Prześnionej rewolucji stały się dla krytyka nadrzędną inspiracją, pozwoliły ustanowić spójny kontekst interpretacyjny. Rzecz Ledera w tekście Krawczyka funkcjonuje na podobieństwo Biblii, jest źródłem kanonicznym, pismem objawionym i podanym współczesnym inteligentom do wierzenia. W podsumowaniu tego obszernego artykułu czytamy:

Baśń o wężowym sercu jest tekstem istotnym i cennym. Poza wartościami stylistyczno-narracyjnymi, do których autor zdążył już swą publiczność przyzwyczaić, książka przynosi uderzający obraz relacji chłopstwa i szlachty, chamów i panów. Może się stać jednym z głosów wybudzających nas ze snu ukazanego przez Andrzeja Lederå ${ }^{8}$.

Przywołuję ów jednowymiarowy komentarz nie bez powodu. Otóż w utworze Raka można zobaczyć donos na rzeczywistość (historyczną, rzecz jasna), powieściową interwencję w sprawie chłopskiej zespoloną z rytualnym „oburzeniem” na skandal pańszczyzny, pendant do utworu Brunona Jasieńskiego, co sygnalizuje rozwinięcie tytułu powieści; słowem, można go czytać socjologicznie, politycznie czy właśnie w perspektywie „rebelianckiej”. Aliści problem

${ }^{7}$ Mam na myśli głosy cyrkulujące w tak zwanej blogosferze książkowej, obecne w rozmaitych witrynach prezentujących nowości wydawnicze. Nie podaję adresów bibliograficznych nie dlatego, że lekceważę nieprofesjonalne świadectwa lektury; nie podaję, gdyż nie jest moim zamiarem rekonstruowanie recepcji krytycznej powieści Raka.

8 S. Krawczyk, Rany od pokoleń niewylizane, „Mały Format” 2020, nr 4-5, http://malyformat.com/2020/05/rany-od-pokolen-niewylizane, dostęp: 23.09.2020. 
polega na tym, że takie postawienie sprawy ma swoją cenę i to raczej wysoką. Należałoby bowiem wziąć w nawias wszystkie elementy, a jest ich ogrom, które nie tylko zakłócają, ale wręcz demolują ową jednowymiarowość, sprawiają, że nie sposób skojarzyć Baśni... z „przypisem do Ledera”. Jeżeli nawet przyjąć, że Radek Rak „używa” Szeli czy też „ożywia” go, kierując się swoimi artystycznymi potrzebami, to chyba nie można powiedzieć, że sens tego „użycia” czy „ożywienia” jest z góry określony. Jestem przekonany, że sytuacja przedstawia się dokładnie odwrotnie - niepodobna ustalić, czego autor Baśni... chce od naszego „zbója”, po co mu ta stara, galicyjska historia.

W wywiadzie, jakiego pisarz udzielił Natalii Szostak, pojawia się niezbyt przekonujące uzasadnienie:

Moi przodkowie byli chłopami. To, co słyszałem w szkole o Szeli, o rabacji, to była narracja kogoś innego. Czułem, że to nie jest opowieść mojej rodziny, to nie jest głos moich przodków. Pomyślałem, że dam głos tym ludziom, którzy go nie mieli. Czyli właśnie chłopom.

Do tego doszło zainteresowanie lokalną historią. Kiedy zgłębiałem rzeczywistość pierwszej połowy XIX w. w zachodniej Galicji, nie mogłem się nadziwić, że tak rzeczywiście mogło być. Uznałem, że także tym czasom należy się opowieść - zupełnie inna niż do tej pory?.

Tak śladów klasowej reorientacji, jak i tropów wskazujących na niezgodę na kulturowe zawłaszczenie w Baśni o wężowym sercu nie dostrzegam. Owszem, Rak sporządził opowieść „zupełnie inną niż do tej pory”, ale nie w imię odzyskania chłopskiej prawdy o chłopskim buntowniku czy - szerzej - ludowej prawdy o „rzeczywistości pierwszej połowy XIX wieku w zachodniej Galicji”. Uczynił coś dokładnie przeciwnego, a mianowicie „ubaśniowił” (umagicznił) „zbója galicyjskiego", dawny antagonizm chłopsko-szlachecki osadził w rzeczywistości mitycznej, postawił na ostentacyjne zmyślenie. Patronat Jasieńskiego, który chciał zobaczyć w Szeli - jak czytamy w odautorskiej Przedmowie do Stowa o Jakubie Szeli - „pierwszego świadomego bojownika interesów chłopstwa”, wypada uznać za zwykłe mydlenie oczu.

W cytowanym tu wywiadzie inna deklaracja - podniesiona przez redakcję do rangi nagłówka - wydaje się niezwykle istotna, ta, która zrównuje Szelę z bohaterami masowej wyobraźni, z Robinem Hoodem i Janosikiem (dziecięco-młodzieńcze uwielbienie, jakim Rak otacza prozę Terry’ego Pratchetta i Johna Ronalda ReuelaTolkiena - mówi o tym w wywiadzie - miałoby także dużą

9 Radek Rak, laureat Nike 2020: Ogladatem Robin Hooda, dziadek skrzywit się. I opowiedziat o Jakubie Szeli, wywiad N. Szostak, „Gazeta Wyborcza”, 11.09.2020, https://wyborcza. pl/7,75517,26248082,kiedy-dziadek-zobaczyl-ze-ogladam-serial-o-robin-hoodzie-skrzywil. html, dostęp: 24.09.2020.

10 B. Jasieński, Stowo o Jakubie Szeli, Warszawa 1956, s. 7. 
wartość dowodową). Czy zatem Radek Rak infantylizuje historię Szeli? Raczej próbuje ją zuniwersalizować, ale jednocześnie popada w wielorakie sprzeczności, których, jak sądzę, nie potrafi przezwyciężyć. Być może najpoważniejszą z nich jest konflikt między historiografią i dyskursem baśniowym. Otóż do opowieści Raka dołączono artykuł popularnonaukowy pióra zaprzyjaźnionego z pisarzem historyka z Uniwersytetu Jagiellońskiego ${ }^{11}$. Elementy składające się na oficjalną, choć zarazem niemożliwą do zrekonstruowania biografię Szeli ${ }^{12}$, pojawiają się tu i ówdzie w Baśni... (zob. na przykład informacje na temat stanu cywilnego Szeli; B, s. 341), ale uwaga czytelnika, z oczywistych powodów, skoncentrowana jest na różnicach. To, że „zbój galicyjski” miał byćjak chcą oficjalne biogramy - kołodziejem i cieśla, nie zaciekawia tak, jak inne wymyślone przez Raka profesje Szeli. Mamy ich ogrom: chłopak na posyłki (w tym szabes goj) zatrudniony przez Rubina Kohlmanna, asystent wiedźmy, przywódca „watahy chamów” (B, s. 177) walczącej z Tatarami, wreszcie - co akurat wydaje się pomysłowe - dziedzic sprawujący władzę w okolicy („skoro Jakób stał się Wiktorynem, to niechybnie Wiktoryn musi się przemienić w Jakóba, albowiem czary nie znoszą pustki”; B, s. 263). Warto się zatrzymać przy tej ostatniej metamorfozie; pozostałe nadprzyrodzone przemiany jawią się jako nazbyt konwencjonalne, wyjęte $\mathrm{z}$ fantastyki obiegu trywialnego.

Motyw przemiany chłopa w pana ma, rzecz jasna, długą i niezwykle bogatą tradycję. Wprawdzie w powieści Raka nie znajdziemy sygnałów wskazujących na źródło inspiracji, ale założyć można, że owa przemiana jest wpisana w opowieść o wyczynach Szeli, stanowi jak gdyby węzłowy punkt obecny w dawnych literackich przedstawieniach, by przywołać w tym miejscu obrazy z dramatu Stefana Żeromskiego (w Turoniu, jak pamiętamy, Szela przejmuje atrybuty pańskiej władzy, wciela się w Krzysztofa Cedrę, właściciela majątku Olszyna). Jednakowoż w trakcie lektury Baśni... pomyślałem o inspiracji idącej od Marka Twaina, albowiem - tak jak w Księciu i żebraku - aktem inaugurującym przejęcie władzy przez fałszywego, ubranego w nie swoje szaty pana stał się akt łaski (u Twaina: chłopiec do bicia nie będzie bity). Przemiana likwiduje tedy przemoc, i to chyba najważniejszy aspekt metamorfozy, która pojawia się w Baśni o wężowym sercu.

Dopowiedzmy, że w świecie wykreowanym przez Raka ów akt łaski wywołuje konfuzję, narusza „odwieczny” porządek:

11 Zob. A.S. Więch, O galicyjskich krwawych zapustach, czyli chtopskim zrywie Jakuba Szeli [w:] R. Rak, Baśń o wężowym sercu albo wtóre stowo o Jakóbie Szeli, Warszawa 2019, s. 448-461. Odwołania do utworu Raka oznaczam skrótem B i podaję numer strony, z której pochodzi cytat.

12 Za Tomaszem Szubertem można powiedzieć, że owa biografia składa się głównie z niewiarygodnych „życiorysów-paszkwili”. Zob. tenże, Jak(ó)b Szela. (14) 15 lipca 1787-21 kwietnia 1860, Warszawa 2014. 
Powiadają, że największy strach padł na chamów, kiedy pan Wiktoryn Bogusz ustami kulawego karbowego Mychajła oświadczył, że w tym roku cięgów za nieodrobioną pańszczyznę nie będzie (B, s. 284).

Inaczej zatem niż u Twaina zamiana ról nie prowadzi do happy endu - raczej podsuwa niepokojącą wątpliwość, kto będzie za chwilę przewodził buntowi w okolicach wsi Smarzowa: pan przemieniony w chłopa, czy chłop przemieniony w pana? Takich ryzykownych konceptów (ryzykownych z punktu widzenia tych, którzy w Szeli chcą widzieć „Django z cyrkułu tarnowskiego” ${ }^{13}$ ) mamy tu sporo. Jak na przykład rozumieć rozliczne interwencje dokonane przez węże (zantropomorfizowane - jak Magura, córka Króla Węży - lub pozostające w swojej zwierzęcej postaci) lub inne „demony” (na przykład gadające ryby o znanych skądinąd imionach Azaradel i Amazarak)? Czy zło obecne w świecie tej powieści ma charakter „metafizyczny” (wiele na to wskazuje), należy do porządku pryncypiów, a w związku z tym wydaje się nieusuwalne? Gdyby tak było, komentowanie dzieła Raka w perspektywie „rebelianckiej” czy „klasowej” (przypominam o „przypisie do Ledera”) podpadałoby pod absurd; baśniowość, którą posłużył się pisarz, bynajmniej nie prowadzi do - jak chciał Krawczyk - „wybudzenia”.

Zaryzykuję uogólnienie: Baśń o wężowym sercu jest utworem pękniętym. Rak próbuje zakotwiczyć swoją opowieść w historycznym i społecznym konkrecie, ale czyni to bodaj bez przekonania. Instrumentarium wzięte z popularnej fantastyki sprawia, że nasz chłopski bohater traci swoją wyjątkowość, a zatem i eksponowane miejsce w polskich dziejach. Dialog podjęty z poematem Jasieńskiego wydaje się, w najlepszym razie, pozorny. W powieści Raka wytropić można tylko jedną scenę, którą wolno nazwać „dialogiczną” - mam na myśli powtórzenie pierwotnej sceny, zawartej w trzeciej części poematu, przedstawiającej spotkanie Szeli z Panem Jezusem. U Raka „zbój galicyjski” wdaje się w króciutką pogawędkę z drewnianym świątkiem, który doń przemówił. Trudno to nazwać wadzeniem się z Bogiem; powiedzieć, że chodzi o złorzeczenie, to posłużyć się eufemizmem. Szela Raka ma dla Pana Jezusa wyłącznie brutalne bluzgi ${ }^{14}$ :

Co się tak, kurwa, gapisz? (...) Z tobą nie warto wchodzić w układy, z tobą dyskutować nawet nie warto. $Z$ diabłów więcej pożytku. - Człowiek splunął Panjezusowi w twarz. (...) Ech, spierdalaj, Panie Boże, i żebym cię więcej nie widział (B, s. 356).

${ }^{13}$ Zgrabne określenie, od którego Łukasz Grzymisławski rozpoczyna notę recenzyjną poświęconą Baśni... (w ramach prezentacji 10 książek roku 2019, „Książki. Magazyn do Czytania” 2019, nr 6, s. 16; nota bez tytułu).

${ }^{14}$ Mimo że Rak zasadniczo troszczy się o urodę języka, posługuje się, acz niekonsekwentnie, całkiem udanymi stylizacjami, nazbyt często, w mojej ocenie, korzysta ze współczesnych wulgaryzmów w rodzaju: „wypierdolili mnie z klasztoru” (B, s. 190), „moczymorda robi cię w chuja” (B, s. 224), „co się tutaj odpierdala” (B, s. 314). 
Wobec pytania o pożytki wynikające z „ubaśniowienia” Jakuba Szeli pozostaję bezradny. Nie tylko nie pojmuję sensu tej operacji, ale i - szerzej - powieść Raka jawi mi się jako utwór co najmniej dziwaczny. Oczywiście nie mogę nie dostrzec osobistego sukcesu pisarza. W cytowanej wcześniej rozmowie z Natalią Szostak krakowski prozaik przyznał, że Baśń... jest jego pierwszą powieścią, która trafiła do szerszej publiczności (dwie wcześniejsze nie miały tego szczęścia). Tymczasem wyróżnienie tego utworu Nagrodą Literacką Nike (edycja za rok 2019) nie tylko wydobyło Radka Raka z anonimowości, ale i zapewniło mu sławę. Jeżeli zatem przyszłoby osadzić pytanie o „pożytki z Szeli” w kontekście, by tak rzec, pragmatycznym (uznanie, prestiż, pozycja), odpowiedź chyba nasuwa się sama.

\section{„Oni wszyscy żyją w nas”. Deutsch dla średnio zaawansowanych Macieja Hena}

Kiedy Marek Deutsch, główny bohater powieści Macieja Hena, odkrywa, że jest potomkiem Jakuba Szeli, wpada w osłupienie. Świadkiem tego oszołomienia, do którego doszło akurat w Rumunii, jest nowa przyjaciółka Marka, Camila, której wypada szybko wytłumaczyć, co to znaczy być późnym wnukiem (pięć pokoleń wstecz) „zbója galicyjskiego”. Marek powiada: „Co byś powiedziała, gdyby się nagle okazało, że wywodzisz się w prostej linii od, powiedzmy, Drakuli?" ${ }^{15}$. Analogia ta młodziutką Rumunkę zrazu rozbawiła, po chwili jednak Camila spoważniała, usłyszawszy, że chodzi o „faceta, który okrutnie wymordował wielu niewinnych ludzi” (D, s. 360).

Sądzę, że pierwsze, wypowiedziane ad hoc skojarzenie jest wielce znaczące (rumuński kontekst wszystkiego nie tłumaczy). Może rzeczywiście w figurze Szeli skumulowały się sprzeczne wątki niczym w postaci Drakuli. Z jednej strony to popkulturowy bohater, którego - przynajmniej źródłowo - kojarzymy z przejmującą grozą, z drugiej zaś strony nie może być współcześnie traktowany serio, wszak w najlepszym razie jest tylko znaną rumuńską „marką”, „ikoną” o niezwykłym potencjale turystycznym i „ciekawostkowym”. A jednocześnie ów transylwański wampir to figura, która nas permanentnie nawiedza, wyłania się z mroku i chce nam zaszkodzić. Oczywiście natychmiast myślimy o Upiorze z Wesela Stanisława Wyspiańskiego, ale to chyba nie ta sama zjawa. Nawet jeśli przyjmiemy, że widmo Szeli czy duch Szeli być może gdzieś krąży, to czy wypada się go lękać? Maciej Hen użył tego widma (ducha) w sposób

15 M. Hen, Deutsch dla średnio zaawansowanych, Kraków 2019, s. 360. Kolejne przytoczenia oznaczam jako D, po przecinku podając numer strony, z której pochodzi cytat. 
dość zaskakujący - w brawurowej i lekkiej zarazem powieści o samopoczuciu dzisiejszego inteligenta ${ }^{16}$.

Mamy rok 2018, do 63-letniego Marka Deutscha, niespełnionego warszawskiego plastyka, zgłasza się kancelaria adwokacka z informacją, że stał się spadkobiercą siedemnastohektarowego gruntu ulokowanego - to pewna niedogodność - w rumuńskiej Bukowinie. To dobra po jego przodku, o którym nie miał pojęcia. Sęk w tym, że prawo do tego spadku nie tylko trzeba staranie udokumentować, ale i zawrzeć porozumienie z drugim spadkobiercą, którym jest przyjaciel Deutscha z młodości (wiele lat temu na skutek niefortunnego nieporozumienia zerwali stosunki). Wprawdzie już na samym początku bohater dowiaduje się (mówi mu o tym adwokat), że ów przodek, po którym zostało siedemnaście hektarów, „był chłopem pańszczyźnianym z Podkarpacia, którego austriackie władze przesiedliły na Bukowinę" (D, s. 24), ale tożsamość praprzodka zgodnie z regułami popularnej powieści o zakroju przygodowym - długo będzie trzymana w tajemnicy. Napięcie musi rosnąć. Tak czy inaczej pierwszy trop wiedzie na ukraińską Bukowinę (Czerniowce, do których Marek jedzie via Lwów), stamtąd bohater rusza do Siedmiogrodu (Braszów), potem ponownie trafia na Bukowinę, tyle że rumuńską - wszędzie, a miejsc tych jest z pół tuzina, wydobywa z parafialnych archiwów dokumenty (metryki chrztów i akty ślubów). Ma już pokaźny pakiet kserokopii i wreszcie, po blisko dwu tygodniach poszukiwań, nie tylko odkrywa, kim był jego antenat, ale i ma w garści komplet dokumentów, które upoważniają go do przyjęcia spadku.

Owa wyprawa pod prąd czasu w poszukiwaniu własnych korzeni prowadzi do kilku innych odkryć, choćby takiego, że przodkowie Deutscha porzucali tożsamość i religię żydowską, lecz w sposób nietypowy (zerwanie z religią przodków, przyjęcie wyznania chrześcijańskiego, a w następnym pokoleniu ponowne wejście do gminy żydowskiej). Bohater powieści zdaje sobie sprawę ze swojego mieszczańskiego rodowodu (solidnego, warszawsko-lwowskiego), ale o żadnych chłopskich korzeniach nigdy nie słyszał; nie znał ich nawet nieżyjący ojciec Marka, z którym - korzystając z poetyki snu - rozmawia główny bohater, obsadzając starego Deutscha w roli genealogicznego konsultanta i doradcy. I tu trzeba powiadomić o wspomnianym wcześniej przyjacielu z lat młodości Deutscha, Danielu Szczepanie Wawrzyńcu Lubicz-Powoyoskim. To arcy-Polak wywodzący się $\mathrm{z}$ arcypolskiej familii o nienagannym rodowodzie szlachecko-ziemiańskim. Tak, on także jest potomkiem Jakuba Szeli, gdyż jeden z jego antenatów zaryzykował mezalians, w związku z czym - powtórzmy - Powoyoskiemu należy się połowa spadku. Komentarz głównego bohatera powieści Hena jest następujący:

${ }^{16}$ Nawiązuję tu do obszernej i niezwykle sugestywnej recenzji Przemysława Czaplińskiego, który wpisał rzecz Macieja Hena w szersze zjawisko nowych obrachunków inteligenckich (w polskiej prozie) - zob. Resztki inteligencji, „Dwutygodnik” 2019, nr 265, https://www.dwutygodnik.com/artykul/8487-resztki-inteligencji.html, dostęp: 23.09.2020. 
obaj nosimy w sobie DNA tego cholernego Jakuba! A jak my dwaj, to pewnie i wiele innych osób, tutaj, w Rumunii, w Niemczech pewnie i gdzieś jeszcze. (...) w gruncie rzeczy przez czysty przypadek właśnie Szela stał się twarzą rabacji. Bo takich jak on lokalnych hersztów było wielu (...), przecież ci inni hersztowie też mieli dzieci i wnuki. Czyli wychodzi na to, że oni wszyscy żyją w nas, w nas wszystkich, bez względu na pochodzenie. Nie jest więc tak, że jedni są od Chama, drudzy od Sema, trzeci od Jafeta. Wszystko się już dawno wymieszało. (...) w każdym z nas siedzą zbrodnie tamtych dni, bestialstwo Szelów, nieludzkość dziedziców. I to, kurczę, bez względu na geny (D, s. 526-527).

Warto dopowiedzieć, że w materię powieści pisarz wplótł mnóstwo wiedzy na temat rabacji i samego Szeli. Wracając z Rumunii do Warszawy, Marek wybiera inną trasę - udaje się na Podkarpacie. Oczywiście po to, żeby zwiedzić okolice wsi Smarzowa, rozeznać się w przestrzeni, wypytać miejscowych o resztki pamięci o Szeli. Nade wszystko jednak - jak na inteligenta przystało - Deutsch cały czas „studiuje”, zrazu wspierając się głównie Wikipedią, a po powrocie do Warszawy od razu biegnie do czytelni Biblioteki Narodowej, gdzie zachłannie czyta wzorcowe opracowania (bohater wyróżnia dzieła Stefana Kieniewicza i Tomasza Schuberta - zob. D, s. 503).

Nie należy zapominać, że „pochodzenie od Szeli” jest tu tylko żetonem w poważniejszej grze biograficznej. Deutscha poznajemy jako spauperyzowanego inteligenta, „prekariusza sektora dekoracyjnego” (jak dowcipnie nazwał go Czapliński), życiowego rozbitka po trzech rozwodach utrzymującego się z nędznych chałtur i nocnego stróżowania. Niezwykle malownicza podróż genealogiczna (malownicza między innymi dlatego, że Hen wykorzystuje schematy pisarstwa popularnego - romansu, powieści drogi, sagi rodzinnej) prowadzi do wieloaspektowej przemiany. Po jej zakończeniu Marek odzyskuje wigor twórczy (teraz chce tworzyć wartościowe obrazy) i erotyczny (młodziutka Rumunka uaktywniła jego męskie moce); zdążył się pojednać z przyjacielem (przed jego samobójstwem, dodajmy, co w finale utworu czyni go jedynym spadkobiercą gruntów po Szeli), coraz lepiej (acz na razie tylko telefonicznie) dogaduje się z córkami - po prostu zyskał nowe, lepsze życie, przebudził się. Spadku jednak nie przyjął, co wydaje się częścią egzystencjalno-moralnego kontraktu. Sporą sumę, która pojawiłaby się po spieniężeniu bukowieńskich gruntów, odrzucił, ponieważ na własne oczy zobaczył, że mieszka tam - w walącej się chałupie, w nędzy - duża rodzina, najpewniej cygańska. Żeby odzyskać tę nieruchomość, trzeba by wynająć „czyścicieli gruntów” (per analogiam do „czyścicieli kamienic"), a także - już całkiem symbolicznie - stanąć po stronie panów, przeciwko którym w 1846 roku wystąpił Szela. Wszak w świetle zarówno starego, jak i obecnego prawa (niektórzy powiadają: odwiecznego) o byciu panem, czyli przedstawicielem warstwy uprzywilejowanej, decyduje między innymi możliwość dziedziczenia dóbr. Tymczasem, jak celnie puentuje Czapliński, wydobywając globalny sens komentowanej tu powieści: 
Zyskiem jest niezależność. (...) Deutsch dla średnio zaawansowanych to historia (...) o zwycięstwie niemierzalnym kryteriami rynkowymi. Na zwycięstwo to składa się przede wszystkim odkrycie w sobie zdolności do stawiania oporu pokusom wyciągania zysków z historii ${ }^{17}$.

Pytam o obecność Szeli (temu pytaniu podporządkowana jest całość podjętych tu dociekań); może bardziej o „pożytki z Szeli”. Jaka tedy będzie odpowiedź wyciągnięta z uroczej powieści Hena? Raczej rozczarowująca. Wszystko, co składa się na dziedzictwo - w ujęciu narodowym, klasowym czy religijnym niesamowicie się wymieszało, a także w dużej mierze zhomogenizowało. Każda podjęta dziś próba „rozczytania” DNA nieuchronnie prowadzi do wniosku, że każdy jest mieszańcem. Formuła „oni wszyscy żyją w nas” nie dotyczy tylko „hersztów”, którzy w połowie XIX wieku zdobyli się na brutalny odwet bohater Hena błyskawicznie, w obrębie tej samej wypowiedzi, uzupełnia to dziedzictwo o klasę panów, ciemiężycieli chłopów, ich katów. Należy też wątpić, że odrzucenie spadku - co wcześniej poniekąd zasugerowałem - ma cokolwiek wspólnego z antagonizmem sprzed blisko dwu stuleci. Jeśli coś tu się kłania, to - by tak rzec i od czego zacząłem - patronat Drakuli. Czy Szela nie jest przypadkiem naszym Drakulą, figurą należącą dziś do stricte popkulturowego imaginarium? Oczywiście stawiam to pytanie z całą świadomością, że wielce ryzykowana to analogia (nie ja ją ustanowiłem, Maciej Hen ją podrzucił). Szela wampirem, którego nie sposób się dziś bać, ale też zjawą, która jakoś nie chce od nas odejść? Chyba jest coś na rzeczy.

\section{Osobliwości. Galicyanie Stanisława Aleksandra Nowaka}

W intrygującej powieści Stanisława A. Nowaka wzmianki o Jakubie Szeli pojawiają się zaledwie na trzech stronach ${ }^{18}$; podane zostały jako zestaw plotek, które krążyły - czy raczej mogły krążyć - w dniach galicyjskiej rebelii. Natomiast motywy bezpośrednio związane z rabacją wypełniają ponad sto stron (G, s. 369-478). Jeśli przyszłoby poszerzyć pole obserwacji o sprawy, które moglibyśmy umieścić pod szyldem „fatalne położenie chłopów w Galicji w pierwszej połowie XIX wieku" ${ }^{19}$, to wówczas otrzymalibyśmy nieledwie pełnowymiarową, liczącą około dwustu stron opowieść o buncie chłopskim

17 Tamże.

18 Zob. S.A. Nowak, Galicyanie, Warszawa 2016, s. 370-372. Kolejne odwołania do tego utworu oznaczam skrótem G.

19 Obok wielu pojedynczych, drobinowych motywów (nazwijmy je obrazkami z życia chłopów pańszczyźnianych) dostajemy także notacje nieledwie „monograficzne” - na przykład mikrorozdziały Palcokosy (G, s. 130-133) i Chtosta (G, s. 166-173). 
z lutego 1846 roku i wydarzeniach, które do tego wystąpienia doprowadziły. Sama rabacja zajmuje w utworze Nowaka eksponowane miejsce z dwu dość oczywistych powodów: po pierwsze, pojawia się w fabularnym centrum opowieści, pośrodku mniej więcej stuletniej ramy czasowej (1812-1915), a po drugie, jest przedstawiana jako najważniejsze, najbardziej spektakularne zdarzenie na tamtych terenach w dziewiętnastym stuleciu. Owe ziemie to wsie ulokowane na południe od Rzeszowa, z których najpełniej odmalowany został Zaborów, wieś rodzinna Kończyświatów (w Galicyanach rozpoznać można strukturę sagi rodzinnej; to opowieść przedstawiająca dzieje czterech pokoleń chłopskiej familii o znaczącym nazwisku).

To, że na temat osoby i czynów Szeli wyłącznie się tutaj plotkuje, nie powinno dziwić. Nasz chłopski buntownik działa przecież w pewnym, acz w sumie niewielkim oddaleniu od Zaborowa, wieść gminna nie tylko jest szczątkowa, ale i pełna sprzeczności, z czego zdaje sobie sprawę wszechwiedzący, nienależący do świata przedstawionego narrator: „ciężko było wymiarkować, co jest prawdą, a co bajeczną mową) (G, s. 371). Plotki o Szeli, kolportowane głównie w zaborowskiej karczmie, przynoszą treści znane nam skądinąd (nawiązując do powieści Hena, można by o nich powiedzieć: z poziomu Wikipedii). To, że „gadano o niejakim Szeli” (G, s. 370), a także przywoływano inne pogłoski o chłopskich buntach wybuchających w całej zachodniej Galicji, ma tutaj kapitalne znaczenie - otwiera dyskurs powieściowy na to, co pozwalam sobie nazwać osobliwością.

Już w tym miejscu podaję myśl ogólną: Nowak bynajmniej nie celuje w odnowienie literackiego opracowania tematu rabacji, nie proponuje reinterpretacji krwawych wydarzeń, pragnie natomiast - to właśnie moja teza - „oczarować” czytelnika, zaintrygować go, odpowiedzieć na jego oczekiwania. Ujmując rzecz w największym skrócie, opowieść o rabacji musi być anegdotycznie atrakcyjna czy też po prostu „ubarwiona”, nastawiona - tak jest w Galicyanach - na paradoks i eksces. Nie znaczy to jednak, że pisarz szuka łatwego porozumienia z czytelnikiem - opowieść Nowaka o rzezi galicyjskiej, chociażby z uwagi na barierę stylistyczną ${ }^{20}$, na pewno nie została spisana z myślą o najmniej

${ }^{20}$ Specjalnie na potrzeby powieści - a utwór to, nawiasem mówiąc, masywny (900 stron gęstego tekstu) - pisarz ustanowił jak gdyby odrębną mowę, którą nazwał ,językiem galicyjskim”. Radykalne stylizacje Nowaka niewiele mają wspólnego z próbą ożywienia bądź przetworzenia jakiejkolwiek lokalnej gwary (tu - ze względu na czas i przestrzeń - używanej w południowej Rzeszowszczyźnie w XIX wieku). Mamy raczej do czynienia z mieszaniną najróżniejszych odmian staropolszczyzny, z niebywałym nagromadzeniem archaizmów i wyrazów rzadko współcześnie używanych. Prawdopodobnie z uwagi na ów radykalizm stylistyczny, mający bez mała utopijny zakrój, debiutanckie wystąpienie Nowaka zostało zlekceważone przez krytykę i czytelników. Powtarzano - adresy bibliograficzne pomijam - że przez język tej powieści niepodobna się przebić, że stanowi on barierę, która broni dostępu do zawartości fabularnej i dyskursywnej utworu. Nie jest też chyba sprawą przypadku, że nieliczne, bardziej zaawansowane komentarze dotyczące Galicyan biorą w nawias wyzwania idące od strony języka tej powieści; do takiego wniosku prowadzi między innymi lektura obszernego szkicu interpretacyjnego Magdaleny 
wymagającym odbiorcy, przyzwyczajonym do ujęć popkulturowych, a więc zazwyczaj uproszczonych i przerysowanych, czasami wręcz komiksowych, obliczonych na prowokacje czy ryzykowne przekroczenia.

Plotki o wyczynach Szeli oraz szczątkowe informacje o postępkach innych „zbójów galicyjskich” są istotne. Fundują bowiem pierwszy, inicjalny paradoks: dobra zaborowskie należą do hrabiego Krzelowskiego, pana „wrażliwego i dobroczynnego" (G, s. 355), który wprawdzie całkiem niedawno stał się właścicielem majątku oraz, rzecz jasna, pracujących dla niego chłopów pańszczyźnianych, ale szybko dał się poznać jako przeciwnik kar cielesnych. Nowak podsuwa iście diabelski dylemat: jak tu, wzorem innych buntowników, ubić hrabiego, skoro ten jest dobrym panem? Jakoś nie wypada... Miejscowi chłopi długo na ten temat debatują, wreszcie dochodzą do wniosku, który narrator oddaje w ten sposób:

Powinni napaść dwór, bo co sobie o nich ludzie pomyślą. Śmiać się z nich będą. W drugich wsiach wszczą się nieład, morderstwa, chłopy dwory pustoszą, a w Zaborowiu spokojność święta. Oni są przymuszeni najść dwór, żeby władze nie przyszły czasem do przekonania, że zaborowiaki też należą do polskiej wojny (G, s. 380).

Dodajmy, że wtóry argument (podejrzenie o udział w szlacheckiej insurekcji roku 1846) nie ma żadnego uzasadnienia - pośród wielu pogłosek, które przechodzą z ust od ust, nie ma ani jednej, która wskazywałaby na groźbę represji ze strony władz wymierzonych w chłopów; przeciwnie - „zaborowiaki” wiedzą, że doszło do sojuszu aparatu przemocy (austriacka administracja i wojsko) z galicyjskim chłopstwem (oczywiście chodzi o alians zmontowany przeciwko polskiej szlachcie). Pierwszy argument jest o wiele poważniejszy okoliczni chłopi boją się posądzenia o nieudacznictwo i marazm („Wszędy pomstują na panów, a u nich - dupa!”, G, s. 379). Błyskawicznie pojawia się dodatkowa przesłanka: bohaterowie Galicyan obawiają się, że rabunków mogliby dokonać obcy, przybysze z sąsiednich wsi, którzy dowiedziawszy się, że „zaborowiaki" odstąpili od splądrowania dworu, zwietrzyliby w tym swoją okazję. Wreszcie pojawiają się we dworze, ale nie po to, by go plądrować. Chcą dogadać się z hrabią; proponują mu, że z całą rewerencją, komfortowo i bezpiecznie zostanie odwieziony do więzienia w Rzeszowie, gdzie spokojnie przeczeka, „aż się wszystko wyhuczy” (G, s. 410). Tak też się dzieje $\mathrm{e}^{21}$, ale „zaborowiaki” nie są zadowoleni z rezultatów pierwszego najścia na dwór, nazajutrz tedy wracaja,

Adamarek (taż, O dziejach pewnego mitu. Na marginesie powieści „Galicyanie” Stanistawa Aleksandra Nowaka, „Fraza” 2018, nr 2, s. 127-137).

${ }^{21}$ Do czasu, gdyż hrabia, po krótkim pobycie z rzeszowskim areszcie, wraca do swojego zrujnowanego majątku. Tam zostaje pojmany przez „czerń”, zrazu jest wymyślnie torturowany, a na końcu przerżnięty piłą wraz z krzesłem, na którym go posadzono (jeden z obserwatorów krwawego spektaklu krzyczy: „Rżnijcie powoli, bo dobry był nam pan!”; G, s. 457). 
już jako „czerniawa”, dziki, wściekły i niezwykle pomysłowy, jeśli idzie o praktyki karnawałowe, tłum.

Nowak nastawiony na osobliwości ma pełne pole do popisu, wszak nie chodzi mu o „zwykłe” opisy plądrowania i dewastowania dworu, zdeponowane zresztą w rozmaitych sprawozdaniach czy wspomnieniach z epoki ${ }^{22}$; troszczy się przede wszystkim o efektowność obrazowania. Czytamy zatem o „niewstydnikach”, którzy z radością defekują w salonie, urządzają wymyślne maskarady. Kiedy zaś skończył się zapas pańskich alkoholi, chłopi „wydudlili wszystko, co było do wydudlenia" (G, s. 446), w tym takie specyfiki, jak apteczne mikstury, łój do wyrobu świec czy „„zwarc do czyszczenia butów” (G, s. 446). Dalsze katalogowanie ekscesów jest chyba zbędne - ich charakter, estetyczne ukierunkowanie wydają się oczywiste. Wypada tylko dodać, że kiedy nasi grasanci odrobinę znudzili się z gruntu dziwacznymi zabawami, przypomnieli sobie o swoich ciemiężycielach. Czytamy o znienawidzonym karbowym (hrabia zostawił go na służbie, choć stosowania przemocy mu zabronił):

Każdy chciał choć raz uderzyć przeklętnika, uciemiężenia odemścić. Niemożebnością było się dopchać. Męczyli go ledwie nie godzinę. Pokaleczyli go, zęby mu wybili, a na ostatku (jeszcze dychał) okapłonili - odcięli mu chwosta i wsadzili do gęby. Bo dziewki psował (G, s. 423).

Ta ostatnia tortura, zadana karbowemu na chwilę przed śmiercią, doskonale mieści się w logice i estetyce przyjętego przez Nowaka obrazowania, które - powtórzmy - ma być przede wszystkim „uwodzicielskie”, a więc ostatecznie naznaczone perwersją. Godzi się lepiej tę prawidłowość zilustrować.

Otóż chłopi z Zaborowa i kilku najbliższych przysiółków spotykają się w ustronnym miejscu zwanym Słonym Dołem, by przy ognisku snuć przejmujące opowieści o doznanych krzywdach. Kiedy mówią o wymierzanych karach cielesnych, odnosimy wrażenie, że liczą się tylko pobicia ze skutkiem śmiertelnym. Oczywiście nie mówią o własnych doświadczeniach, bo przecież owe gawędy nie są wypowiadane przez tych, których zamęczono na śmierć. Szczególne walory anegdotyczne - zarówno z punku widzenia chłopów gawędziarzy,

22 Ich status jest oczywiście niepewny. Nie potrafimy dziś rozstrzygnąć, czy mamy do czynienia ze „świadectwami”, czy raczej z aktualizacją pewnych „wzorów narracyjnych”, za pomocą których zwykło się oddawać grozę krwawej rebelii. To drugie z wziętych w cudzysłów określeń zaczerpnąłem z dzieła, które ukazało się już po napisaniu niniejszego artykułu (A. Leszczyński, Ludowa historia Polski. Historia wyzysku i oporu. Mitologia panowania, Warszawa 2020). Czytamy tam: „Ówczesne relacje z masakry przypominają do złudzenia opisy wcześniejszych powstań chłopskich, od Chmielnickiego po koliszczyznę, powielając ten sam wzór narracyjny" (s. 327). Leszczyński nie tylko zwraca uwagę na powtarzające się przez 200 lat (od połowy XVII wieku do połowy wieku XIX) schematy, w których ujmowany był karnawał przemocy, ale i wspomina o konkretnych, niezwykle do siebie podobnych, torturach zadawanych panom przez zrewoltowanych chłopów. 
jak i czytelników Galicyan - mają tortury z jakąś nadwyżką okrucieństwa. Dogodnym przykładem jest tortura wymyślona przez Poddziedzica dla Jacentego Wilka, polegająca na przywiązaniu nieszczęśnika do krzesła z wyciętym dnem, do którego przytwierdzono wiadro z wygłodniałymi szczurami. Po kilku dniach gryzonie - jak czytamy -,,wyjadły zadek Wilka Jacentego”, „żyły się w dupie porwały” (G, s. 397). Krnąbrny „cham” jakimś cudem przeżył, a kiedy nadszedł luty 1846 roku, zaborowscy chłopi zobaczyli w Jacentym idealnego mściciela, jednego z „męczycieli, którzy potrafiliby zadać boleść” (G, s. 396). Słowem, w Galicyanach chłopski odwet za doznane od panów krzywdy nie może się ograniczyć do zgładzenia znienawidzonych szlachciców oraz ich nadgorliwych pomagierów, w grę wchodzi brutalny mord poprzedzony torturami, a te muszą być dla efektu i ku naszej lekturowej „przyjemności” - naznaczone jakąś perwersją.

W tym właśnie trybie snuje Nowak swoją opowieść o rzezi galicyjskiej i potwornościach, które do wybuchu chłopskiej rebelii doprowadziły. Autor Galicyan chce być sarkastyczny, szuka osobliwości w paradoksach, w historycznie niepotwierdzonych lub udokumentowanych tylko częściowo „dziwactwach”, które w tamtych dniach dały znać o sobie. Taką sprawą jest bez wątpienia „handel ubitymi szlachcicami” (G, s. 393). Nowak odwołuje się tutaj do chłopskiej mądrości, która wzięła się rzekomo z urzędniczej głupoty: „Starosta tarnowski, kreiskapitan Breinl, nałożył cenę za głowę Polaka: za schwyt żywego 5 reńskich złotych, za ubitego dwoje tyle - 10 reńskich złotych" (G, s. 393). Ekonomiczny absurd! Wyłonił się tedy podział pracy: zaktywizowali się ci, którzy na potęgę wyłapują ,każdego, kto nosi się z pańska albo po ekonomsku” (G, s. 392), oraz ci, którzy „odkupują” schwytanych od łowców, a w drodze na posterunek lub do urzędu cyrkularnego mordują pojmanych motywowani chęcią podwojenia zysku. Co więcej, szybko ukształtowała się geografia handlu ubitymi szlachcicami. Handlarze zwłokami „wiozą ubitych tam, gdzie ich lepiej ohandlują. Nie do Wadowic, a do Bochni, nie do Jasła, bo tam nijak trupów nie skupują" (G, s. 395). Ceny zresztą spadają - w takim Sanoku płacą już tylko 4 złote reńskie za szlacheckie truchło.

Łatwo ulec literackiej inwencji Nowaka - istnieje pokusa, żeby wyimków, z uwagi na zawarte w nich osobliwości, dać więcej. Na przykład drugie tyle na temat mordowania księży i profanowania miejscowej świątyni. Tutaj zresztą pisarz również wychodzi od fundamentalnego paradoksu, który można przedstawić w formie pytania: jak uzasadnić antyklerykalny szał, który w jednej chwili wybucha w niezwykle klerykalnym ${ }^{23}$, nieledwie zaczadzonym katolicką dewocją środowisku? Jednakowoż ucinam w tym miejscu - reguły obrazowania w całej powieści są takie same, a więc zorientowane na wyróżnione przeze mnie osobliwości.

23 „Religijność zaborowiaków była dużo wielga. Do kościoła przychodzili tłumno. (...) Na msze dążyli jak żywina ciągnąca do wodopoju” (G, s. 425). 


\section{Podsumowanie}

Ponieważ zająłem się powieściami, które poznaliśmy albo przed chwilą (utwory Radka Raka i Macieja Hena), albo stosunkowo niedawno (rzecz Nowaka), świadomie posłużyłem się trybem wypowiedzi właściwym dla krytyki literackiej. W ten właśnie sposób próbuję uzasadnić obecność sądów wartościujących oraz to, że poszczególne prezentacje różnią się od siebie, także pod względem sympatii okazywanej powieściopisarzom. Chcę jednak wierzyć, że ogóle wnioski są niezagrożone; konkluzje bardziej szczegółowe, dotyczące trzech wybranych przeze mnie powieści, umieściłem w artykule.

Pierwsze uogólnienie wydaje się najbardziej oczywiste: innej niż popkulturowa lub quasi-popkulturowa obecności Szeli (bądź motywu rabacji) nie sposób się dziś spodziewać; innej, czyli związanej na przykład z dyskusją o wspólnotowości narodu polskiego czy kwestią przywracania ludowi podmiotowości. Zapewne jest tak, że lata dwudzieste XX wieku to ostatni moment, kiedy można było poważnie rozprawiać o Szeli, prawdziwie lękać się chłopskiego gniewu, zajmować się rachunkami krzywd w duchu obywatelskiej troski ${ }^{24}$. Komentowane przeze mnie utwory $-\mathrm{i}$ to wniosek drugi $-\mathrm{w}$ gruncie rzeczy niewiele mają wspólnego z poruszeniem zwanym zwrotem plebejskim, i to nie tylko dlatego, że brak im odpowiedniej powagi czy, jakkolwiek rozumianej, doniosłości. Przede wszystkim niepodobna dostrzec $\mathrm{w}$ tych powieściach ambicji „rozrachunkowych" (wydobywanie skandalu poddaństwa chłopów polskich, lamenty nad domniemaną trwałością kultury i mentalności folwarcznej, upominanie się o rzekomo wyparte czy niesłusznie zaniedbane chłopskie dziedzictwo itd.). Wreszcie wniosek trzeci powiązany zresztą z wcześniejszą konkluzją: fantazmatyczna figura mściciela („Django z cyrkułu tarnowskiego”) czy - szerzej - fantazje o buncie i odwecie wyprowadzone z niezwykle sugestywnego spektaklu $W$ imię Jakuba S. zawisły bodaj w próżni. Co oczywiście wcale nie znaczy, że spostrzeżenia Przemysława Czaplińskiego, od których zacząłem, przestały być inspirujące. Owszem, Jakub Szela może być patronem obecnie uciskanych Polaków, zwłaszcza przedstawicieli klasy średniej i prekariatu, ale akurat w rozważanych przeze mnie przykładach do takiej funkcjonalizacji nie doszło; „zbój galicyjski” i temat rabacji okazały się atrakcyjne z zupełnie innych powodów.

${ }^{24}$ Zob. J. Wierzejska, Cena chtopskiej krwi. Motyw rabacji w literaturze międzywojennej a wspólnotowość narodu polskiego II Rzeczypospolitej [w:] Chtopska (nie)pamięć..., dz. cyt. 


\section{Bibliografia}

Adamarek M., O dziejach pewnego mitu. Na marginesie powieści „Galicyanie” Stanistawa Aleksandra Nowaka, „Fraza” 2018, nr 2.

Czapliński P., Przemieszczenia. O powojennej prozie chtopskiej [w:] Migracyjna pamięć, wspólnota, tożsamość, red. R. Sendyka, T. Sapota, R. Nycz, Warszawa 2016.

Czapliński P., Resztki inteligencji, „Dwutygodnik” 2019, nr 265, https://www. dwutygodnik.com/artykul/8487-resztki-inteligencji.html, dostęp: 23.09.2020.

Grochowski G., Kwestia chtopska [w:] Chtopska (nie)pamięć. Dziedzictwo chtopskości w polskiej literaturze i kulturze, red. G. Grochowski, D. Krawczyńska, G. Wołowiec, Kraków 2019.

Grzymisławski Ł., [nota bez tytułu] [w:] 10 książek roku 2019, „Książki. Magazyn do Czytania" 2019, nr 6.

Hen M., Deutsch dla średnio zaawansowanych, Kraków 2019.

Jasieński B., Stowo o Jakubie Szeli, Warszawa 1956.

Krawczyk S., Rany od pokoleń niewylizane, „Mały Format” 2020, nr 4-5, http:// malyformat.com/2020/05/rany-od-pokolen-niewylizane, dostęp: 23.09.2020.

Leder A., Nienapisana epopeja. Kilka uwag o zapomnianym wyzwoleniu, „Teksty Drugie" 2016, nr 6.

Leszczyński A., Ludowa historia Polski. Historia wyzysku i oporu. Mitologia panowania, Warszawa 2020.

Nowak S.A., Galicyanie, Warszawa 2016.

Radek Rak, laureat Nike 2020: Ogladatem Robin Hooda, dziadek skrzywit się z pogarda. I opowiedziat mi o Jakubie Szeli, wywiad N. Szostak, „Gazeta Wyborcza”, 11.09.2020, https://wyborcza.pl/7,75517,26248082,kiedy-dziadek-zobaczyl-ze-ogladam-serial-o-robin-hoodzie-skrzywil.html, dostęp: 24.09.2020.

Rak R., Baśn o wężowym sercu albo wtóre stowo o Jakóbie Szeli, Warszawa 2019.

Rauszer M., Bękarty pańszczyzny. Historia buntów chtopskich, Warszawa 2020.

Ryś P.W., „Zwrot plebejski” we wspótczesnej polskiej humanistyce i debacie publicznej [w:] Historia, interpretacja, reprezentacja, t. 3, red. L. Mokrzecki, M. Brodnicki, J. Taraszkiewicz, Gdańsk 2015.

Szubert T., Jak(ó)b Szela. (14) 15 lipca 1787-21 kwietnia 1860, Warszawa 2014.

Więch A.S., O galicyjskich krwawych zapustach, czyli chtopskim zrywie Jakuba Szeli [w:] R. Rak, Baśń o wężowym sercu albo wtóre stowo o Jakóbie Szeli, Warszawa 2019.

Wierzejska J., Cena chtopskiej krwi. Motyw rabacji w literaturze międzywojennej a wspólnotowość narodu polskiego II Rzeczypospolitej [w:] Chtopska (nie)pamięć. Dziedzictwo chtopskości w polskiej literaturze i kulturze, red. G. Grochowski, D. Krawczyńska, G. Wołowiec, Kraków 2019. 